\title{
Diffuse idiopathic skeletal hyperostosis and central cord syndrome after minor trauma: a case report
}

\author{
Diffüz idiyopatik iskeletsel hiperosteozis ve minör travma sonras1 \\ santral kord sendromu: Olgu sunumu
}

Olcay ESER, ${ }^{1 *}$ Ergün KARAVELIOĞLU,${ }^{2 \dagger}$ Mehmet Gazi BOYACI, ${ }^{1 *}$ Abdullah AYÇİÇEK ${ }^{3 \rrbracket}$

Diffuse idiopathic skeletal hyperostosis (DISH) is characterized by anterior and lateral ossification of the vertebral body. We present a case report of central cord syndrome in a patient with DISH after minor trauma. The patient was treated surgically. We also discuss symptomatology and the common mechanism of cord injury in DISH.

Key Words: Central cord syndrome; diffuse idiopathic skeletal hyperostosis; dysphagia; Forestier's disease; trauma.
Diffüz idiyopatik iskeletsel hiperosteozis (Dİ̈H) vertebra korpusunun ön ve lateralinin kemikleșmesiyle kendini gösteren bir durumdur. Bu yazıda, Dİ̈H'li bir olguda minör travma sonrası santral kord sendromunu sunduk. Hasta cerrahi olarak tedavi edildi. Ayrıca DïlH'nin semptomlarını ve kord yaralanmasının ortak mekanizmalarını tartıştık.

Anahtar Sözcükler: Santral kord sendromu; diffüz idiopatik skeletal hiperosteozis; disfaji; Forestier hastalığı; travma.
Diffuse idiopathic skeletal hyperostosis (DISH) is characterized by anterior and lateral ossification of the vertebral body. ${ }^{[1,2]}$ This rare entity is also known as Forestier's disease, occurs mostly in males and in the fifth decade of life, and is rarely associated with systemic diseases such as diabetes mellitus and obesity. ${ }^{[3]}$ The osteophytes are generally located in the thoracic, lumbar and cervical vertebrae $(97 \%, 90 \%, 78 \%$, respectively). The entire vertebral column is affected in $70 \%$ of all cases. ${ }^{[4]}$

Although most of cases are asymptomatic, dysphagia is the most common symptom due to esophageal compression by anterior osteophytes at the C4-5 level. Other symptoms and signs are cervical subaxial pain, stiffness and decreasing range of motion of the cervical spine.

\section{CASE REPORT}

A 67-year-old male applied to our emergency department with dysphagia, numbness and tetraparesis. His complaints started after a minor trauma one month before and worsened progressively. On his neurological examination, he had tetraparesis $(+2 / 5$ motor strength), hypoesthesia on his four extremities and upper neuron findings such as hyperreflexia and Babinski sign. There was no sensation or sphincter reflex but he had normal anal reflex.

$\mathrm{X}$-rays and cervical computed tomography (CT) revealed bony ankylosis from $\mathrm{C} 2$ to $\mathrm{C} 6$ without any fractures or dislocation (Fig. 1a, b). Cervical spine magnetic resonance imaging (MRI) demonstrated spinal stenosis at the C3-4 level with both anterior and posterior compression, myelomalacia and slight cord

\footnotetext{
Departments of ${ }^{1}$ Neurosurgery, ${ }^{3}$ ENT, Afyon Kocatepe University Faculty of Medicine, Afyonkarahisar;

${ }^{2}$ Bolvadin Dr. HI Ozsoy State Hospital, Afyonkarahisar, Turkey.

Current affiliation:

*Department of Neurosurgery, Balikesir University Faculty of Medicine,

Balikesir; †Department of Neurosurgery, Afyon Kocatepe University

Faculty of Medicine, Afyonkarahisar; \#Diyarbakir Silvan State Hospital,

Diyarbakir; ФDepartment of ENT, Afyon Kocatepe University Faculty of Medicine, Afyonkarahisar, Turkey.
} 

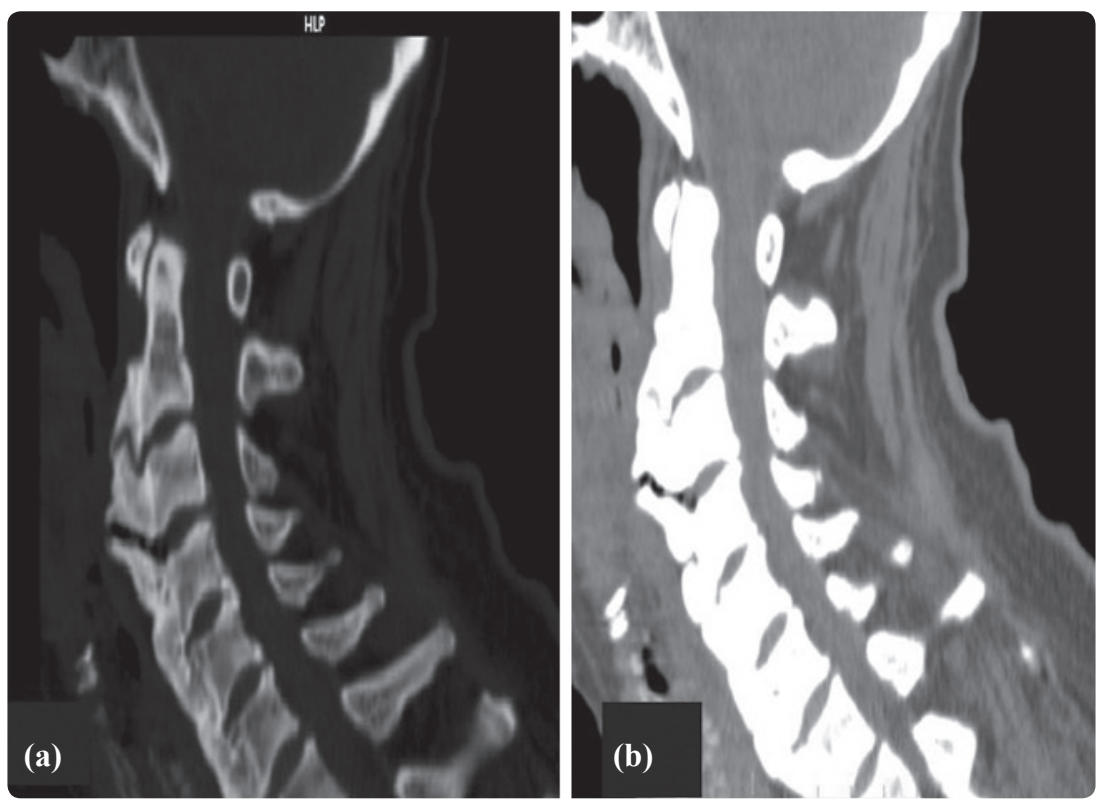

Fig. 1. (a, b) Bony ankylosis from $\mathrm{C} 2$ to $\mathrm{C} 6$ without any fractures or dislocation.

edema (Fig. 2). At surgery, C3-4 total laminectomy, C2-C5 lateral mass screws and C3-4 anterior microdiscectomy and fusion with cage and plate were performed (Fig. 3). He had minimal dysphagia at the sixmonth follow-up after surgery.

\section{DISCUSSION}

Diffuse idiopathic skeletal hyperostosis is characterized by calcification and ossification of the ligaments, tendons and fascia. It has an estimated prevalence rate of up to $10 \% \cdot{ }^{[5]}$ The spine is mostly involved followed by the pelvis, patella, calcaneus, and olecranon. ${ }^{[4]}$

The suggested pathogenesis of DISH indicates that ossification and new bone formation are the result of abnormal osteoblast cell growth/activity in the bony ligamentous region. ${ }^{[6]}$ In the literature, studies have reported that patients with DISH have high insulin and growth hormone levels. ${ }^{[7]}$ As is well known, insulin-like growth factor 1 (IGF-1) stimulates alkaline phosphatase activity and type II collagen production in osteoblasts, and growth hormone can induce the local development of IGF-1 and IGF binding proteins in chondrocytes and osteoblasts, which explains the osteoblast cell growth and proliferation. ${ }^{[8]}$

Diffuse idiopathic skeletal hyperostosis incidence increases with age and is very rare in the first four decades of life. Obesity and type 2 diabetes mellitus are major risk factors. Other risk factors include hypervitaminosis $\mathrm{A}$, high body mass index and hyperuricemia..$^{[4,9,10]}$

This rare disease is usually asymptomatic and diagnosed incidentally. The most common symptoms of DISH are pain and stiffness, dysphagia and decreased range of motion. ${ }^{[4]}$ Dysphagia can be explained by four different hypotheses: 1) anterior bony fragments projecting between the C4-C6 level, causing rigid and fixed pharynx and esophagus, which cannot move easily while swallowing; 2) the presence of large anterior osteophytes and direct compression of the esophagus;

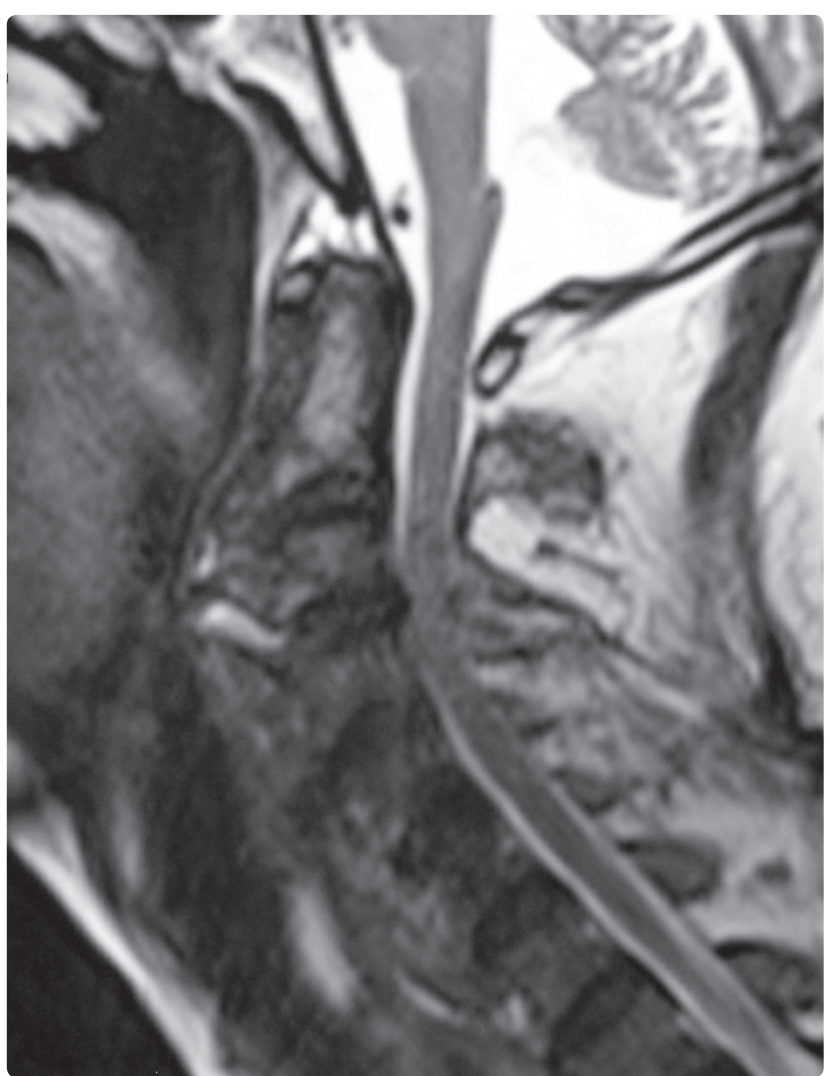

Fig. 2. Spinal stenosis at the C3-4 level with both AP compression, myelomalacia and slight cord edema. 

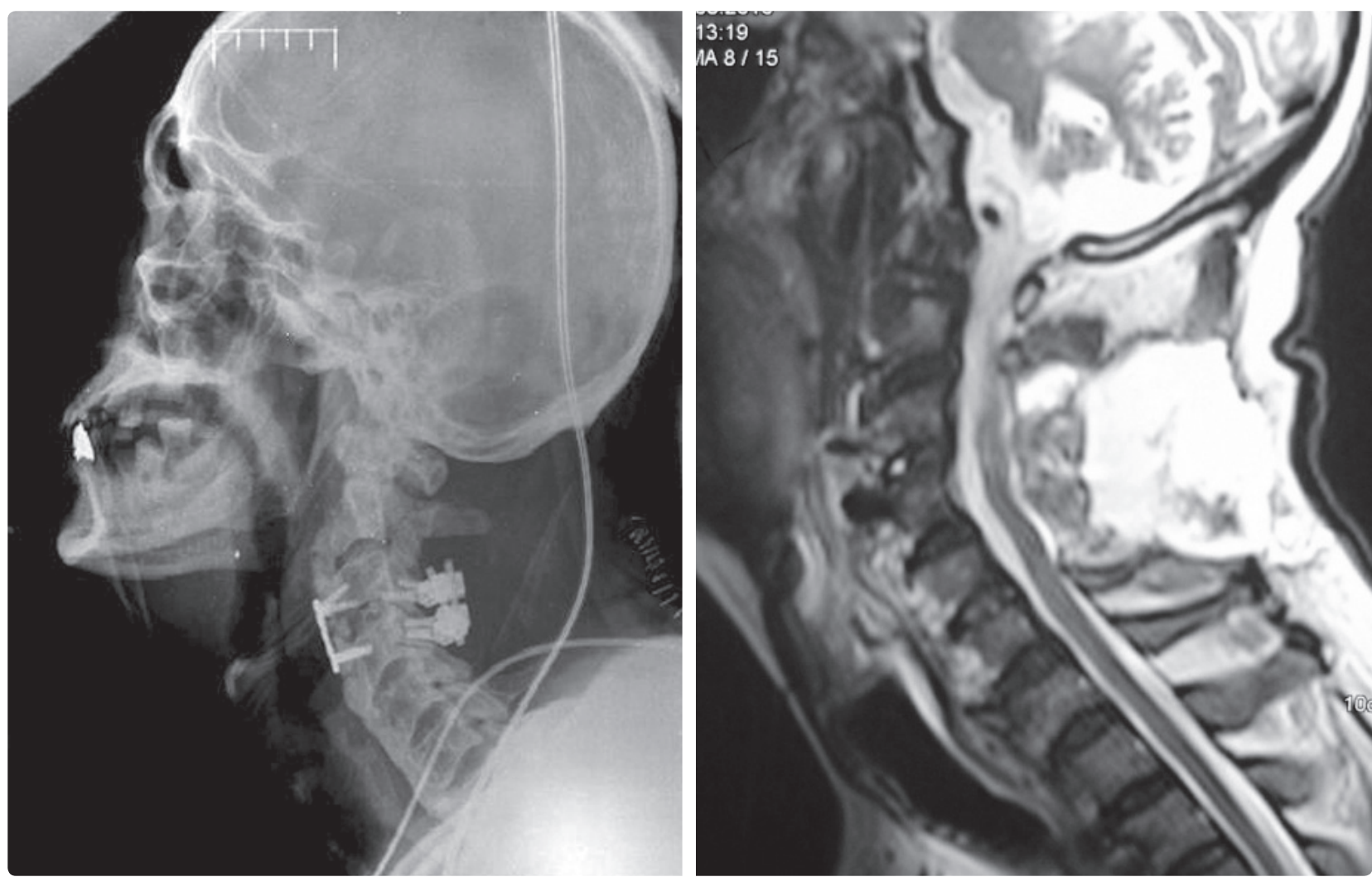

Fig. 3. At surgery, C3-4 total laminectomy, C2-C5 lateral mass screws and C3-4 anterior microdiscectomy and fusion with cage and plate were performed.

3) inflammation around the esophagus, causing swelling of surrounding tissues, and 4) reflex spasm in the cricopharyngeal segment provoked by pressure of solid bolus on osteophytes.

Involvement of the cervical spine is the primary cause of the neurological findings. This is due to the reduced flexibility of the spine, spinal canal narrowing secondary to ossification of anterior and posterior longitudinal ligaments and atlantoaxial subluxation of the cervical spine. ${ }^{[4]}$

The diagnosis of DISH is based mainly on data obtained from the radiological evaluation: 1) Presence of flowing new bone formation on at least four contiguous vertebral bodies; 2) Absence of degenerative disc disease and relative preservation of intervertebral disc height; and 3) Absence of inflammatory changes in facet or sacroiliac joints. ${ }^{[4,11,12]}$

The management of patients with DISH is mostly conservative including nonsteroidal antiinflammatory drugs (NSAID) and steroid therapy. Surgery including anterolateral, posterolateral and transoral approaches could be an appropriate choice in patients with severe and progressive symptoms. ${ }^{[13,14]}$ The anterolateral approach in particular provides better exposure of large osteophytes and the large cervical vessels and vagus nerve, but more attention should be given regarding recurrent laryngeal nerve palsy. ${ }^{[9]}$

While several articles have reported DISH presenting with compressive symptoms, the authors report herein DISH causing cervical cord compression and central cord syndrome. There are few reported cases of DISH coexisting with ossified posterior longitudinal ligament giving rise to neurological sequelae as a result of minor trauma to the neck.

Conflict-of-interest issues regarding the authorship or article: None declared.

\section{REFERENCES}

1. Carlson MJ, Stauffer RN, Payne WS. Ankylosing vertebral hyperostosis causing dysphagia. Arch Surg 1974;109:56770.

2. Ladenheim SE, Marlowe FI. Dysphagia secondary to cervical osteophytes. Am J Otolaryngol 1999;20:184-9.

3. Resnick D, Shaul SR, Robins JM. Diffuse idiopathic skeletal hyperostosis (DISH): Forestier's disease with extraspinal manifestations. Radiology 1975;115:513-24.

4. Cammisa M, De Serio, Guglielmi G. Diffuse idiopatic skeletal hyperostosis. Eur J Radiol 1997;27:7-11.

5. Bessetle L, Katz JN, Liang MH. Differential diagnosis and conservative treatment of rheumatic disorders. In: Frymoyer JW, Ducker TM, Weinstein JN, editors. The adult spine: Principles and practice. 2nd ed., Philadelphia: Lippincott-Raven 
Publishers; 1997. p. 821.

6. el Miedany YM, Wassif G, el Baddini M. Diffuse idiopathic skeletal hyperostosis (DISH): is it of vascular aetiology? Clin Exp Rheumatol 2000;18:193-200.

7. Atzeni F, Sarzi-Puttini P, Bevilacqua M. Calcium deposition and associated chronic diseases (atherosclerosis, diffuse idiopathic skeletal hyperostosis, and others). Rheum Dis Clin North Am 2006;32:413-26, viii.

8. Vetter U, Zapf J, Heit W, Helbing G, Heinze E, Froesch ER, et al. Human fetal and adult chondrocytes. Effect of insulinlike growth factors I and II, insulin, and growth hormone on clonal growth. J Clin Invest 1986;77:1903-8.

9. Akhtar S, O'Flynn PE, Kelly A, Valentine PM. The management of dysphasia in skeletal hyperostosis. J Laryngol Otol 2000;114:154-7.
10. Smythe H, Littlejhon G. Diffuse idiopathic skeletal hyperostosis. In: Klippel JH, Dieppe PA, editors. Rheumatology. 2nd ed., London: Mosby; 1997. 8 10.1-10.6.

11. Resnick D, Niwayama G. Radiographic and pathologic features of spinal involvement in diffuse idiopathic skeletal hyperostosis (DISH). Radiology 1976;119:559-68.

12. Resnick D. Degenerative diseases of the vertebral column. Radiology 1985;156:3-14.

13. Oga M, Mashima T, Iwakuma T, Sugioka Y. Dysphagia complications in ankylosing spinal hyperostosis and ossification of the posterior longitudinal ligament. Roentgenographic findings of the developmental process of cervical osteophytes causing dysphagia. Spine (Phila Pa 1976) 1993;18:391-4.

14. Meeks LW, Renshaw TS. Vertebral osteophytes and dysphagia. Ann Otol Rhinol Laryngol 1970;79:1091-7. 